\title{
Cardiac Teratoma
}

National Cancer Institute

\section{Source}

National Cancer Institute. Cardiac Teratoma. NCI Thesaurus. Code C147007.

A teratoma that arises within the myocardium or cardiac chambers. 